\title{
A NEW COUNTY MUSEUM
}

The Museums and Contract Archaeology

\section{Richard Grönwall}

\section{A CHANGED MUSEUM LANDSCAPE}

The deregulation of Swedish contract archaeology at the end of the I990s fundamentally changed the conditions for the work of the regional museums. Whereas archaeological assignments had formerly been an important part of the museums' general work on behalf of society, they have since been increasingly regarded as a separate side branch of their work. Contract archaeology, however, has continued to be important for many museums, not just for the development of knowledge but also for the possibility of financing broader competence than would otherwise have been possible. The development of contract archaeology towards a market that is admitted regulated by the state but is still subject to competition has simultaneously proven to be difficult to combine with the role of public representatives in heritage management. Is it the consultant who makes the statement, and whose interests do the museums actually represent? The relationship to Länsstyrelserna (the County Administrative Boards) has also changed since the deregulation, since a museum's contract activity is perceived as an obstacle to formal cooperation. The requirements for purchasing publicly financed 
heritage management measures have further increased the distance between the county administrative boards and the museums, for example, concerning the former traditional museum assignment of managing ancient monuments and setting up signs at historic sites, which in certain counties today is entrusted to private entrepreneurs to undertake, paid with public money in return for state funding.

During my years as an archaeologist and head of section at Stockholm County Museum, I have been able to follow development at close quarters. Perhaps it is only now, after nearly two decades of competitive contract archaeology, that I can reflect with some detachment on the development and its consequences for museum archaeology. Though it must be added that there are still regional differences in the potential of the museums to pursue contract archaeology in Sweden, and that my perspective is that of the metropolitan region. The greatest changes have probably taken place in Stockholm County, a region with a generally high volume of contracts per year and a large number of actors in the sector. However, a similar trend can be expected in other parts of the country over the years to come, as the market 'matures' and businesslike, competitive companies develop. The question that ought to be asked is therefore perhaps not how the regional museums will perform in the competition, but how they instead can adapt to fulfil the public assignment of communicating the cultural heritage to the citizens.

\section{GOOD AND BAD ARCHAEOLOGY}

There are no studies showing that publicly owned contract archaeology is any better in quality than privately owned contract archaeology, or vice versa. The issue of whether such functions should be publicly owned or privately run is rather a matter of ideology, not a question of good or bad archaeology. My stance is that it is the public supervision of the work of contract archaeology companies that must ensure that such work is performed in accordance with society's needs and demands not whether the tasks are carried out by public institutions or private companies. The fact that contract archaeology in Sweden is exempted from the Public Procurement Act probably means that there is more direct public control than in many other sectors. How well the system works in practice is of course another matter, but this will not be explored further here.

Let us instead consider the key question: Is regional museum archaeology endangered and becoming extinct? If the term regional museum 

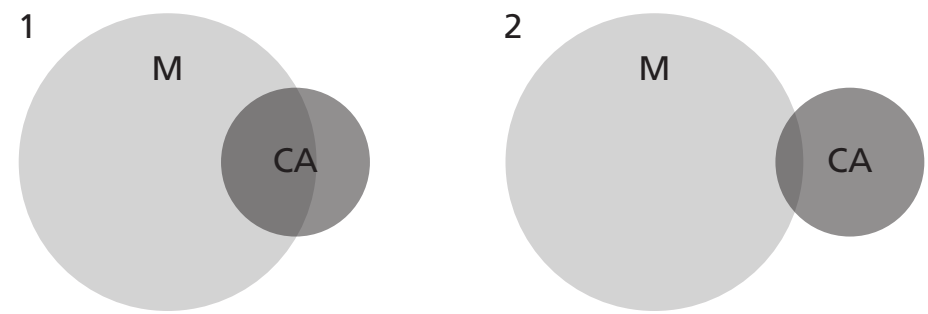

Figure I. The relative movement of contract archaeology (CA) from the museums (M) to other actors over time.

archaeology is to be understood as the archaeological activities traditionally pursued at the county museums, and based on its own work in contract archaeology, then the answer must undoubtedly be yes. This is not to say that this is necessarily negative for museum archaeology in a broader sense.

Figure $\mathrm{I}$ is a schematic illustration of how contract-financed archaeology has moved over time from the museums to other actors. The first stage reflects the situation before deregulation, when regional and municipal museums carried out many of the archaeological assignments, in 'competition' only with the excavation department of Riksantikvarieämbetet (the National Heritage Board). The second stage reflects today's situation, where a much smaller proportion of excavations is performed by the museums, while a growing share is now undertaken by private actors.

To a large extent, then, the regional museums have already lost the ground on which museum archaeology traditionally rested, and there is very little to suggest that this trend will be reversed. But why have the museums found it so difficult to compete with the private companies? To begin with, it may be noted that the total volume of archaeological contracts in Sweden is relatively small, with an annual turnover of only 300-500 million kronor on a national basis. ${ }^{\mathrm{I}}$ For most regional museums it is very difficult to keep up competitive excavation activity confined to one county. Looking for contracts outside the county could be envisaged as a conceivable solution on purely commercial grounds, but that would scarcely be in keeping with the purpose of a regional museum, and in many cases it would also mean competing with other regional museums that find themselves in the same situation. What then would need to happen if archaeology is not to disappear as a subject and a basis for knowledge development at the regional museums?

1 In the absence of national statistics, the figure is an estimate. 


\section{CLEARER ROLES - MORE ARCHAEOLOGY}

For many regional museums, work with the cultural heritage is closely associated with the practical work of heritage management pursued within their own region, which includes contract archaeology. The fact that a large share of the work today is done by actors who view the museums as competitors is of course a problem. When Länsstyrelserna also regard the museums as consultants on the same footing as private archaeological companies, the situation becomes even more problematic. The kind of mediation and communication that is linked to an individual excavation is part of the assignment today. One cannot expect, however, that more long-term goals and strategies for communicating and developing knowledge on the basis of the results of contract archaeology will be the main focus of private archaeological companies. That would require a different type of organization, competence and networks, which in turn requires long-term and expensive investments with a highly uncertain economic yield. For such work there are already established institutions - the public museums.

Instead there can be reason to aim for a clearer division of roles between the actors in order to develop contacts between private archaeological companies, regional museums and their target groups. For this to happen, however, it may be necessary for the museums to stop pursuing contract archaeology in competition with others, which may also seem inevitable today for purely economic reasons.

Figure 2 illustrates a conceivable future scenario with regional museums no longer pursuing contract archaeology. A new interface can then be developed for collaboration between museums and archaeological companies, where ongoing dialogue about the goals for knowledge development and communication can take place. A division of roles like this ought to bring new conditions for increasing the quality of methods and knowledge production in contract archaeology and also improving communication with the citizens. At the same time, the museums could

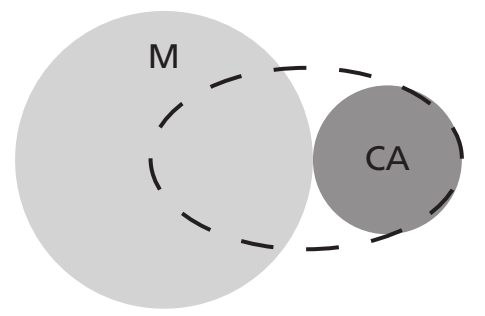

Figure 2. A suggested future relationship between museums $(\mathrm{M})$ and private actors working with contract archaeology (CA). 
resume closer formal cooperation with Länsstyrelserna, for example, in fields such as quality control and supervision of companies working in contract archaeology.

There is no doubt that we face immense challenges and that major changes are necessary. But I think it is exaggerated and pessimistic to believe that the museums will be forced to abandon the subject of archaeology as a consequence of the competition. In order to compete, the regional museums should instead develop a new and clearer role as institutions with the task of communicating the work of contract archaeology in collaboration with the companies that do it. Then there is a possibility that the museums will also attain the conditions needed for long-term knowledge development in cooperation with county administrative boards, universities and archaeological companies. 